\title{
The European Model of Sport: Values, Rules and Interests ${ }^{1}$
}

\author{
V. Zuev, I. Popova
}

\begin{abstract}
Vladimir Zuev - Professor, Institute for Trade Policy, National Research University Higher School of Economics; Room 407, Building 1, 17 Malaya Ordynka, Moscow, Russian Federation; E-mail: vzuev@ hse.ru
\end{abstract}

Irina Popova - PhD student, National Research University Higher School of Economics; Researcher, Centre for International Institutions Research, Russian Presidential Academy of National Economy and Public Administration; 20 Myasnitskaya, 101000 Moscow, Russian Federation; E-mail: impopva_1@ edu.hse.ru; popova-im@ranepa.ru

\begin{abstract}
Recent transformations in the ways that modern sport is managed have fundamentally changed its role in society; previously a simple form of leisure activity and health promotion, sport has become a complex phenomenon and a multibillion dollar business. The combination of sociocultural and economic dimensions makes sport an important tool for the promotion of interests. A leading role in the development of sport throughout history gives the European Union (EU) an advantage in setting the rules for its management, while the size of the sports market in Europe further facilitates the EU's leading role in developing the regulatory basis in this field. The sports model developed by EU institutions plays an important role in the deepening of regional integration processes, promoting the European model outside the region and also the EU's transformation into one of the drivers of the development of the global sports management system.

The goal of this article is to identify the specificities of the European model of sport, the instruments and resources used by the EU to promote European values in this field and the universal features of the European approach that make it applicable in other regions. The analysis shows that the EU actively promotes its values, norms and interests by entrenching them into the European sport model and then promoting this model to other countries and regions.

Practices and norms developed in the European context are being actively transferred to the international level. Sport, and especially football which is the most popular and among the most profitable sports, has become another area in which European management practices demonstrate their consistency and are being actively applied at the global level.

The spread of the European sports model is facilitated by the "spillover" of EU law to the organizations and institutions in which it participates. The EUmodel is promoted through soft power supported by the authority of the European sports federations and the leading position of the European sports market. By elaborating its own sports policy and encouraging its spread to other regions, the European Union is driving the development of sports management practices at the global level.
\end{abstract}

Key words: European Union; European Union's sports policy; European model of sport; sports policy; European Union's values; American model of sport; European Union's sports law

For citation: Zuev V., Popova I. (2018) The European Model of Sport: Values, Rules and Interests. International Organisations Research Journal, vol. 13, no 1, pp. 51-65. (In Russian and English.) DOI: 10.17323/1996-7845-2018-01-03

${ }^{1}$ The editorial board received the article in September 2017.

Support for Zuev V. from the 2018 Individual Research Program of the School of World economy and International Affairs at National Research University - Higher School of Economics is gratefully acknowledged. 


\section{Introduction}

In the last few decades sport has gained unprecedented popularity, attracting more and more attention and resources, both financial and human. Recent transformations in the ways that modern sport is managed have fundamentally changed its role in society; from a simple form of leisure activity and health promotion, it has become a complex phenomenon and a multibillion dollar business. At the same time, the combination of sociocultural and economic dimensions makes sport an important tool for the promotion of interests. The importance of sport as a global phenomenon which both exerts a growing influence on the behaviour of the masses in different countries and generates powerful financial flows underscores the need for its international regulation.

Europe has always been a major centre for sports development. Since the birth of the ancient Olympic Games until the present, organizational innovations have been developed and implemented in Europe and later distributed around the world. This historical leadership in sports development provides the European Union (EU) with a great opportunity to set the trend in the formulation and articulation of the rules and management system. The EU's leading role in shaping the regulatory basis of sport is ensured by the size of the sports market in Europe. The sports model developed by EU institutions plays an important role in deepening regional integration processes, the promotion of the European values and interests outside the region and the EU's transformation into one of the major drivers of the global sports management system.

Because this area of research has only recently begun to attract attention in academic circles, there are not yet many complex or deep studies of the European approach to sports management. At the moment, the most sustained attempts to explain how football is related to political and economic processes in Europe can be found in the work of a group of German scientists at the University of Cologne (Groll, Gutt, Mittag "Political aspects of football in the European Union") and research sponsored by the Fédération Internationale de Football Association (FIFA) and conducted by Mathew Holt [2006]. The bulk of the literature on this topic is made up of articles dealing with very specific issues.

Economic theory is the leading field within sports research. Some scientists, for example Vladimir Andreff, consider sports research to be the most promising trend in the development of modern comparative economy, which "has slightly lost its positions after the actual disappearance of the socialist economy" [Andreff, 2011].

Rather than comparative economy, institutional economics is the more appropriate approach to studying sports because it is more theoretically flexible and because the EU's sports model is not profit but utility driven. This approach is applied to analyze the transfer market and the behaviour of sports clubs in it, the organization of major sporting events and the adoption of various restrictions by the Union of European Football Associations (UEFA). It is also used to assess the reaction of clubs and leagues to crucial decisions such as the introduction of the "financial fair play" principle which aims to change the policies of major players. Stefan Szymanski is rightfully considered 
the main expert in this field of research. He has developed a theoretical approach to understanding the specific characteristics of the European sports model using various economic, mathematical and econometrics models.

Recently, research on the political dimension of football in addition to the economic one has gained popularity. Research within international relations and other fields within political science investigating the connection between sport and integration processes in Europe has gained momentum. Scientists like Jeremy Wells, Wolfram Mancenreiter, Georg Spielater, Jurgen Mittag, Benjamin Legrand and Roger Levermore explain how football influences identity construction and how this can be used to strengthen or weaken nationalist sentiment in society. They also demonstrate how the world's number one sport can be used to deepen the various aspects and processes of Europeanization.

There are also studies of various lobbying instruments provided by the multilevel governance system in the European Union that can be used by sports federations in their struggle for the relative independence of sport. Borja Garcia and Henk Meyer [2007] analyzed the activities of the sports movement in the fight for the explicit mention of sport in the treaties on the functioning of the European Union. Richard Parish [2003b] analyzed the attitude of various interest groups to the exemption for sport in the European legal system.

The purpose of this article is to identify the specificity of the European model of sport management, shed the light on the instruments and resources the European Union exploits to promote European values in this field and determine what factors make the European approach universal, helping it to expand to other regions of the world.

\section{Features of the European Sports Model}

The Lisbon Treaty on the Functioning of the European Union, among many other innovations, has extended its competence to the sphere of sports by formulating the general legal framework and articulating the main policy directions in this field. ${ }^{2}$ The extensive practice of joint management of different sports in Europe, supported by the legal foundation of the Lisbon Treaty, forms a common model of sport for the EU. Its main principles were previously formulated in the White Paper on Sport and in the European model of sport document developed by the European Commission [Holt, 2006]. The provisions on sport development contained in these basic documents enable the European Union to make the most effective use of this sphere to promote its interests and strengthen the single European identity in the region [Zuev, 2016].

The White Paper was issued on 11 July 2007, right before the economic crisis of 2008, and was the first comprehensive and thoroughly elaborated initiative by the European Commission to formulate a consolidated position on the development of sports in the region [Hill, 2009]. It defines the basic provisions on sport as a new area of

${ }^{2}$ Art.165 Treaty of Functioning of the European Union 
EU policy, formulates the main directions for the development of the European sports movement and identifies specific tools for implementing policies. The document also lays out the fundamentals of sports organization - the features of the management system and the specifics of the regulation of economic aspects, taking into account its social function.

The provisions on the "specificity of sport" formulated in the White Paper were used to construct a management system in this area. The development of this process was especially active after the adoption of the Nice Declaration. The White Paper of 2007 identified the specificity of sport, and any exemptions this specificity may imply regarding the application of EU legislation to the sphere of sports. In general, legislators considered the premise that sport is a type of economic activity which falls under the system of European economic law. Despite this general approach, the specificity of sport is acknowledged and, according to the White Paper, manifests itself in several aspects: first, in the organization of separate competitions for men and women, the need to limit the number of participants, the need to ensure the unpredictability of the outcome of sporting events and to maintain a competitive balance between the teams participating in the competition; and second, in the independence and high autonomy of sports structures, in the large variety of sports organizations, in the pyramidal principle of conducting competitions from amateur to professional, in the mechanism of forming organizations on a national basis and of having only one federation for each sport [Siekmann, 2012].

The White Paper also states that the specificity of sport should be taken into account in the decision-making process by the European Court of Justice and the European Commission. It postulates that the adoption of judicial decisions in this area, as in other spheres of the economy, is based on the precedent principle such that each case will be considered separately. Thus, the elaboration of legal norms in this sphere is within the framework of case law and may not even presuppose the formulation of additional special legal norms in the basic EU treaties. In this way, a sport management system in the EU was constructed.

At the moment, the dominant discourse in the sphere of sport regulation is the development of the European dimension in sport. The goal to strengthen and promote this approach is set by the Lisbon Treaty (Art.165). The development of the European dimension is indicated as the main objective in all of the main documents issued after the adoption of a new Treaty on the Functioning of the European Union (TFEU). Conceptually, the European dimension involves the need to take into account and equally develop the social, economic, cultural and organizational functions of sports. In addition, it aims to promote European management practices outside the EU, primarily through the Council of Europe.

The official position of the EU on the role played by sport in the process of integration development is expressed in the definition and consolidation of five main functions in the White Paper on Sport. 
1. Educational function: sports help to form a multifaceted personality, providing self-development for people of all ages.

2. The function of maintaining the health of society: exercise helps improve the health of the population, helps fight various diseases and allows preserving the quality of life of all generations.

3. Social function: sport is an ideal environment for creating greater social inclusion and preventing intolerance, racism, sexism, cruelty, alcohol and drug use. Sport helps to involve different segments of the population in the labour market.

4. Cultural function: sport contributes to better adaptation, helps to assimilate cultural norms, forms a special type of identity.

5. Recreational function: sport is the optimal and useful form of leisure for the population [European Commission, 2007].

Interestingly, the model was not initially meant to be imperative and was instead framed as a recommendation. All countries and sports associations were invited to submit drafts for alternative models or amendments to the existing one. Perhaps the comprehensiveness of the option proposed by the European Union explains why alternative options were not submitted for consideration. The European model of sports developed in 1998-1999 emerged as dominant in Europe and was later consolidated in the White Paper and the Lisbon Treaty [Garcia, 2007].

The elaboration of the sport management system is based on the basic principles of the European sports model, which cover all aspects of the given social phenomenon. They form the organizational component of sports in Europe [Garcia, 2007].

The first organizational principle is a pyramidal, hierarchical management structure that includes four levels. Clubs are at the bottom of the pyramid, offering the opportunity for everyone to join the sports movement and enjoy the benefits of sports. At this level, the most important task is to make sport accessible to all ("sport for all"). Regional federations consist of clubs and unite all teams of a certain region or locality. National federations regulate processes related to a specific sport in a particular country, ie., they organize competitions, solve problems and so on. They have a monopolistic position within their country, as they are the sole bodies regulating a particular sport. They also have representation in European governing bodies. European federations constitute the top of the pyramid and include national federations. They determine the rules of the game as they occupy the highest position in organizing European competitions.

The second important principle is the promotion-relegation system. The pyramidal structure implies the subordination not only of the levels of regulation and management, but also of all competitions given that they are organized on all the levels of the pyramid. Any football club which successfully plays at the regional level can enter the national championship, and then the European one. This is the basis of the promotion system. However, the process also works in the opposite direction: a team that is weak in the national championship and takes one of the last places goes to the lower division. This is the basis for the relegation system. It is believed that due to vertical 
mobility between the leagues, competitions become more interesting and their overall level increases. Selection for European competitions is carried out in accordance with successes in the championships at the national level of the pyramid [European Commission, 2007].

The third important principle is the regulation of broadcasting rights. The European Union reserves the right to intervene in a seemingly purely market process, emphasizing the importance of the social function that sport implies. The EU seeks to ensure equal access to the display of leading sporting events for all, therefore it secures wholesale broadcasting rights and limits the activities of private cable and satellite companies to prevent the domination of paid television and the excessive commercialization of sports. The European Commission notes the three advantages of such a system of selling broadcasting rights: first, it creates a single point of sale reduces transaction costs; second, it increases the recognition of the competition as a brand, and; third, it creates a unified product of the league oriented not to individual clubs but to competition in general [European Commission, 2007].

The basic principles for the broadcasting of sports events are consolidated in the "television without borders" directive approved by the European Commission. This directive is the basis of the audiovisual policy of the European Union. It implies the free movement of content and programs released in the countries of the Union throughout its territory and the requirement to maintain certain quotas of air time for European content on all television channels. The aim of this directive is also to promote and protect such vital public interests as cultural diversity, the protection of minorities and the right to self-expression [European Commission, 2007].

\section{The Consolidation of European Sports Models}

Formally, in the field of sports, the EU has only a minimal supporting competence, as described in Article 165 of the TFEU. However, it would be a serious mistake to believe that the EU's activities are limited to mere coordination and support in the field of sports [Parrish, 2003a]. A more detailed examination of the EU's competence shows it to be much deeper and wider. The activities of sports organizations such as UEFA fall under the full extent of European law in the field of competition policy, single market and freedom of movement [Vermeersch, 2007]. In these policies, the EU has maximum exclusive competence. Dependence of the UEFA on the decisions of the EU was confirmed in the Bosman case involving a Belgian football player who could not be transferred to the desired club because of the " $3+2$ " rule. ${ }^{3}$ Since 1995 , when a decision on this case was made by the European Court of Justice, all transfer and other rules introduced by UEFA are discussed with the Commission and are tested for compliance with European law. The situation is similar for another important aspect - the introduction of financial fair play in football. Based on the analysis of the application

${ }^{3}$ Case C-415/93 Union Royale Belge des Sociétés de Football Association v Bosman [1995] ECR I-4921 
of this practice, it can be concluded that the EU is the dominant party in the process of defining the legal and organizational framework for sports management in Europe, and the autonomy of the sports federations is very limited.

The implementation of this model and its principles, and the promotion of the embedded values, allows the European Union to effectively use the opportunities that sport in general and football in particular provide for the creation of a common European identity and the dissemination of European norms and regulations. The key tool for the consolidation of the European management model is the membership of non-EU countries in regional sports organizations. It is necessary to take into account the fact that the functional principles of these organizations are determined within the political and legal space of the EU.

The foundation of the European sports model is constituted by those values that it is designed to protect. Promotion of universal values manifests in the "European dimension in sport." The emphasis on combating such negative phenomena as gender inequality, racism and violence, combined with the proclamation of the traditional civilizational components of European identity (tolerance, respect and equality of opportunities for all) makes this model a manifesto of EU leadership in establishing value orientations for other countries and regions and confirms the EU as a normative power.

The design of the European model - a pyramidal, clearly delineated hierarchical management system in all sports - provides necessary and sufficient subordination and unified execution of decisions at all levels of the pyramid [Roche, 2004]. The most important policies are developed at the level of European sports federations and flow down from there. The deviation from the rules adopted at the European level leads to the disqualification of any federation or club that violated the rules. And since European competitions are the most prestigious and profitable, non-admission to participation in them is associated with high costs for clubs. The desire to participate in European competitions thus provides voluntary, rather than compulsory, subordination to existing rules [Zuev, 2016].

Decisions taken by sports associations at the European level, for example by the UEFA, must comply with European law [Parrish, 2008]. Softer recommendations and more strict regulations made by the European Union to European sports federations flow down though all levels of the pyramid without undergoing changes, as the associations themselves forbid arbitrary interpretation of the adopted European norms. Otherwise, they will face soft pressure from the EU or even full sanctions from the Commission. The costs for associations in case of violation will be much higher than the benefits they receive being part of the pyramid. Therefore, they are interested in a strict implementation of European norms in an undistorted form. This implementation mechanism facilitates the most efficient use of the formal, technical and legal vertical integration processes which constitute the normative and legal basis for the Europeanization of sport.

A vivid example of policy in the field of sports developed in accordance with the European Union's approach is football management. Introduction of the principle of 
financial fair play in football is an interesting case. The key point of the new club licensing system was the breakeven criterion: from the moment the rules came into effect, restrictions were imposed on the level of clubs' expenses so that they do not chronically exceed the level of income. Interestingly this resembles the policy aimed at financial recovery of the banks and national budgets of EU countries. Financial fair play is a joint product of collaboration between the UEFA and the European Commission and is based on the provisions of competition policy, namely, the regulation of state support. ${ }^{4}$ The main objectives of the introduction of the new system to license participation in European competitions were: improving the financial performance of clubs, protecting creditors, strengthening the discipline in financial management, increasing reliable long-term investments in football and sustainable development of European football in the long run [UEFA, 2015].

The requirement of positive economic and financial performance and compliance with the criterion of self-sufficiency has its roots in traditional EU principles of good governance [Zuev, 2016]. The range of activity of such practices, however, is not limited to the European Union, since non-EU countries participate in UEFA competitions. Therefore, the application of the financial fair play principle consolidates the normative power of the EU, contributing to the strengthening of its position in the region.

Implementation of the other principle of the European sport model - the promotion-relegation system - provides the link between amateur and professional sports, incorporating them into the general system and preventing the complete separation of these spheres of activity. Such a link activates the vertical bottom-up integration processes. The chance of promotion creates an additional incentive for the development of amateur clubs and teams. They, in turn, are included in the decision-making system and become active participants in the process [Crolley, Levermore, Pearson, 2002]. Taking into account the interests of amateur sports is an important aspect of common identity formation, since it facilitates the implementation of the fundamental principles of the EU as a whole: a grassroots approach and solidarity.

An important aspect of the regulatory system is the establishment of the centralized sale of rights to broadcast sports events and the promotion of a unified format for their coverage. This affects the process of creating a single brand of sports competition, helps to increase its recognition, enhances access to broadcasting and increases attendance at matches. The organization of the broadcasting rights market, which is the third important principle of the European model of sport, meets the need to create a common European identity and facilitates the development of both its civil and cultural components.

The creation of a popular brand of European competitions attracts viewers from different countries, both members and non-members of the EU [Martin, 2005]. The unified perception of the competition is one of the conditions for further convergence, which increases the likelihood of consensus and the development of a unified policy.

${ }^{4}$ Joint Statement by Vice-President Joaquin Almunia and President Michel Platini on Financial Fair Play, 21 March 2012. 
In the process of promoting a single European brand of sports competition, the cultural component of European identity is involved. It is necessary to mention the great influence and symbolic significance of the largest sports competitions in Europe, such as, for example, the EURO and the Champions League. Given the crucial role that football plays in the lives of Europeans, these continental tournaments begin to take on a role as symbols of unity, along with the anthem, flag and citizenship. The existence of a common competition signals the unity of the European continent. Interaction in the framework of the Champions League raises awareness of culture and life in other states of the European Union, as well as in countries throughout Europe. A large number of matches and the continuous nature of tournaments such as the Champions League are actively used to encourage centripetal tendencies in Europe.

The universalization of the coverage of sports events on the territory of European states plays an important role too. It creates an opportunity to embed the desired common European discourse into the information and value spaces dominated by the national media of each country [Inthorn, 2010]. As sports federations, especially the UEFA, are directly influenced by the EU and fall under its regulatory system, the rules for covering events and sporting broadcasts become a channel for the distribution of Europeanized content. This in turn creates a positive perception of Europe and the EU as a cultural phenomenon and contributes to the development of European identity.

Of particular importance is the organization of away matches, during which fans get acquainted with the historical, cultural, sports, gastronomic, economic, political and other arrangements of other European states [Levermore, Millward, 2007], and collect the most attractive elements of these systems for transfer to their own territories. Such trips to the countries of the Union lead to an understanding of the problems of other countries, the overcoming of stereotypes, the gradual formation of a common perception of many events and the removal of barriers. In essence, there is a common system of representations and a single interpretation of events by representatives of different states. This creates the fundamental prerequisites for the development of cooperation and deepening of integration. Crossing the borders of states within Europe allows sports lovers to fully understand the advantages of four freedoms and a single European citizenship that consolidates European values and European identity.

Even the renaming of the European football championship to EURO, registered as an independent brand, was deliberately intended to emphasize the solidarity of the states in one more area. This rebranding turned out to be not only a successful marketing move but also had a symbolic significance, since the tournament is designed as a pan-European holiday that generates centripetal tendencies in Europe.

Integration momentum will be further strengthened by the holding of EURO 2020 in 13 UEFA member countries. The absence of a single venue will make this tournament truly European, linking the different corners of Europe from Spain to Azerbaijan. The opportunity to visit several European sports capitals in different countries and get acquainted with cultures and everyday life across Europe will make a positive contribution to the continent's consolidation. 
Another important aspect of the regulatory framework that is relevant to the EU and to many other regions of the world is the ratio between national and regional components in the development of different policies. The European sports model, on the one hand, postulates the principle of national identity in sports competitions. On the other hand, the model itself aims to strengthen and develop the common European identity in every possible way. The way it is done becomes clear through the consolidation of the principles of club football in the region.

The system of rules regulating the functioning of clubs and the competition design ensures that coaches and athletes are selected by their qualities, and not by nationality. The composition of players is completely international. And the clubs themselves attract fans who live far beyond their own countries. The Champions League is the most prestigious football club competition in Europe and the world, shown by the statistics of views, the size of the prize money and the turnover of financial flows. For many clubs and their fans, the season is considered successful if the team was able to win a spot in the European Cups; this task is given a higher priority than even the result of the national championship [Martin, 2005]. This bias towards European club football is used by the European Union to weaken nationalist sentiments. Associating oneself with the club leads to the creation of new forms of identity among the fans, different from traditional nationalism, as a European club is not purely a national phenomenon anymore.

Thus, promoting the established principles and values together with the European model of sports, the European Union actively implements and develops its mechanism for management in this area. It first affects the countries of the near neighbourhood, and consolidates the EU's regional leadership in the field of sports.

\section{Expansion of the European Sports Model to the International Level}

The application of the European model of sport goes beyond the borders of the region and has become a powerful tool for projecting and promoting European norms, values and interests at the global level [Levermore, Millward, 2007]. The authority of European sports federations makes them important actors in defining the vectors for the development of various spheres of increasingly globalized sport. Of course, the European model is not the only one in the world. In disciplines that have major audiences outside Europe, alternative mechanisms of governance are applied. The European federations are not trendsetters, for example, in cricket. The main alternative is the American model, which is based on completely different principles. The North American sports model aims, first, to extract the maximum profit. Unlike the European model, it is characterized by closed leagues based on permanent membership secured by the purchase of a franchise. Also, in American competitions there is no promotion-relegation system since there is no pyramidal structure. Entry to the league is achieved by buying a franchise. Moreover, salary caps are used to limit the race for athletic talents, keeping 
wages at an acceptable level. Exchange of players is mainly conducted through a system of barter whereas the purchase of players for money is either limited or prohibited. The broadcasting rights for the competitions belong to clubs which manage them at their discretion.

The American model is applied in basketball, hockey and baseball. Outside the United States, this model does not have a scale of distribution typical for the European model. In many countries, the U.S. model in these sports is implemented only partially, taking into account local circumstances.

In general, both models (which are rather Weberian ideal types and are adjusted when implemented on practice) have their own strengths and shortcomings, stemming from the socio-cultural and institutional characteristics of the respective regions. In the U.S., professional sport is considered to be a business and is governed by the principle of gaining maximum profit. At the same time, amateur sports are an integral part of the culture and lifestyle of Americans. In Europe, maximizing utility rather than profit prevails, and policymakers do not want to separate professional and amateur sports into individual spheres.

Football, one of the most popular sports, originated on the European continent and began to develop as a professional sport there. Therefore, from the very beginning, management traditions were promoted by Europeans to other countries. However, dominance in establishing the rules of regulation did not lead to the unconditional leadership of European teams in the world. And this is understandable. No sole regulatory environment determines successes in a specific area such as sports. For example, Latin American countries have successfully implemented European rules and regulations in the field of sports in general, and football in particular, and began to act on an equal footing with Europeans even surpassing them in many respects. This happened because the European model is largely universal; it can produce results and serve as a stimulus to the development of sports in virtually any international and national environment.

The popularity of football in Europe and beyond turns it into a distinct social and political phenomenon. Awareness of the significance of this game made it an instrument in the hands of dictators to demonstrate the superiority of their nation during the times of totalitarian fascist and communist regimes. At the same time, football is used today to promote the principles of democracy and respect for human rights. For the European Union, maintaining the dominant position in determining the direction of development of this particular sport is especially important.

In the countries of the European Union, sports - football in particular - have become a major sphere of the economy. According to some estimates of the European Commission, sports generate about $3 \%$ of the gross domestic product. The high level of institutionalization of sports and advanced management mechanisms that ensure maximum transparency and protection of the interests of all actors increase competitiveness, which in turn preserves the leading positions. European clubs have gradually become the richest and most attractive employers for athletes from around the world. 
As the main talents flock to Europe (sports, coaching, management), this provides European federations with even more power.

Thus, under these influences and by getting the best from various objective factors, European sports federations have been able to strengthen their position as significant actors in global sport management. Therefore, the practices and norms developed at the European level are actively and fairly successfully broadcasted to the international level.

\section{Conclusion}

Models of organization and regulation of different types of activities developed within the framework of regional organizations go beyond their regions, are translated to the international level and are widely implemented by many national, regional and international organizations. This contributes to the establishment and consolidation of universal governance mechanisms at the global level. One of the leaders, perhaps even the sole leader, in the development of modern trends in advanced global governance is the European Union. Its normative leadership in various fields has evolved over the years and as a result has determined the EU's significant place in international political and economic relations. Sport, and especially football as the most popular and most profitable sport, has become another area in which European management practices have demonstrated their consistency and are being actively applied at the global level. The spread of the European model of sport is facilitated by the "spillover" of EU law to the organizations in which it participates. The EU model is promoted through soft power, backed by the authority of the European federations and the leading positions that the European sports market occupies. The European Union, taking steps to dynamically develop European sports, has become a driver of the application of its management practices at the global level.

\section{References}

Andreff W. (2011) Some Comparative Economics of the Organization of Sports: Competition and Regulation in North American vs. European Professional Team Sports Leagues. The European Journal of Comparative Economics, vol. 8, no 1, pp. 3-27.

Crolley L., Levermore R., Pearson G. (2002) For Business or Pleasure? A Discussion of the Impact of European Union Law on the Economic and Socio-Cultural Aspects of Football. European Sport Management Quarterly, vol. 2, no 4, pp. 276-295.

European Commission (2007) European Model of Sport, Discussion Paper for the Working Group. Available at: http://ec.europa.eu/sport/library/documents/b1/doc424_en.pdf (accessed 19 January 2018).

Garcia B. (2007) UEFA and the European Union: From Confrontation to Co-Operation? Journal of Contemporary European Research, vol. 3, pp. 202-223.

Hill J. (2009) The European Commission's White Paper on Sport: a Step Backwards for Specificity? International Journal of Sport Policy, vol. 1, no 3, pp. 253-266. 
Holt M. (2006) UEFA, Governance and the Control of Club Competition in European Football. London: Football Governance Research Centre, Birbeck University of London.

Inthorn S. (2010) Europe Divided, or Europe United? German and British Press Coverage of the 2008 European Championship. Soccer \& Society, vol. 11, no 6, pp. 790-802.

Levermore R., Millward P. (2007) Official Policies and Informal Transversal Networks: Creating "PanEuropean Identifications” through Sport? The Sociological Review, vol. 55, no 1, pp. 144-164.

Martin P. (2005) The "Europeanization" of Elite Football. Scope, Meanings and Significance. European Societies, vol. 7, no 2, pp. 349-368.

Parrish R. (2003) The Politics of Sports Regulation in the European Union. Journal of European Public Policy, vol. 10, no 2, pp. 246-262.

Parrish R. (2003) The Birth of European Union Sports Law. Entertainment Law, vol. 2, no 2, pp. 20-39.

Parrish R., Miettinen S. (2008) The Sporting Exception in European Union Law, The Hague: TMC Asser Press.

Roche M. (2004.) Europe, "the Cosmopolitan Condition" and International Sport: "Cultural Europeanisation" and EU Regulation in the Case of European Football. Working paper presented at 'Europe and Cosmopolitanism' conference, Royal Holloway College, London University.

Siekmann R. (2012) Introduction to International and European Sports Law, The Hague: T.M.C. Asser Press, p. 210.

UEFA (2015) UEFA Club Licensing and Financial Fair Play Regulations. Available at: http://www.uefa. com/MultimediaFiles/Download/Tech/uefaorg/General/02/26/28/41/2262841_DOWNLOAD.pdf (accessed 19 January 2018).

Vermeersch A. (2007) All's Fair in Sport and Competition? The Application of EC Competition Rules to Sport. Journal of Contemporary European Research, vol. 3, no 3, pp. 238-254.

Zuev V.N. (2016) Global'nye instituty regulirovanija [Global Regulatory Institutions]. Moscow: Magistr, Infra-M. (In Russian.) 


\title{
Европейский подход к управлению в сфере спорта: ценности, нормы и интересы ${ }^{1,2}$
}

\author{
В.Н. Зуев, И.М. Попова
}

Зуев Владимир Николаевич - Д.э.н., профессор Института торговой политики факультета мировой экономики и мировой политики Национального исследовательского университета «Высшая школа экономики»; Российская Федерация, 119017, Москва, ул. Малая Ордынка, д. 17, стр. 1, каб. 407; E-mail: vzuev@hse.ru

Попова Ирина Максимовна - аспирант Национального исследовательского университета «Высшая школа экономики» (аспирантская школа по политическим наукам), младший научный сотрудник Центра исследований международных институтов Российской академии народного хозяйства и государственной службы при Президенте РФ (РАНХиГС); Российская Федерация, 101000, Москва, ул. Мясницкая, д. 20; Е-таil: impopova_1@edu.hse.ru; popova-im@ranepa.ru

Трансформации, которые произошли в управлении спортом, в корне изменили его значение в обществе: из простой формы досуга и укрепления здоровья он превратился в сложный, многомиллиардный, хорошо управляемый бизнес. Сочетание социально-культурной и экономической составляющих делает спорт важным инструментом продвижения интересов. Историческое лидерство в развитии спорта дает Европейскому союзу веские основания задавать тон в формировании системы правил его управления, как и во многих других областях. Ведушую роль ЕС в формировании регулятивной основы спорта обеспечивает и размер спортивного рынка в Европе. Разработанная институтами ЕС модель спорта играет важную роль в углублении региональных интеграционных процессов, продвижении европейской модели за пределы региона и в превращении его в драйвер становления глобальной системы управления спортом.

Цель данной статьи состоит в выявлении специфики европейской модели управления спортом - за счет каких инструментов и ресурсов Европейский союз утверждает европейские ценности в этой области, что позволяет европейскому подходу быть универсальным и распространяться на другие регионы.

Анализ показал, что, внедряя сложившиеся в объединении принципы эффективного управления и ценности в Европейскую модель спорта и распространяя ее на другие страны и регионы, Европейский союз активно продвигает свои интересы. В первую очередь это касается стран ближнего окружения, что закрепляет региональное лидерство ЕС в сфере спорта.

Однако разрабатываемые на европейском уровне практики и нормы также активно транслируются и на международный уровень. Спорт, и особенно футбол как самый популярный и экономически наиболее выгодный вид, стал еще одной сферой, в которой европейские практики управления продемонстрировали свою состоятельность и активно применяются на глобальном уровне.

Таким образом, распространению Европейской модели спорта способствует «перетекание» права ЕС на организации, в которых он участвует. Модель ЕС популяризируется «мягкой силой», за счет авторитета европейских федераций и лидирующих позиций, которые занимает европейский спортивный рынок. Европейский союз, динамично развивая европейский спорт, превратился в драйвер применения практик управления и на глобальном уровне.

Ключевые слова: Европейский союз; политика Европейского союза в сфере спорта; Европейская модель спорта; политика в сфере спорта; ценности Европейского союза; Американская модель спорта; спортивное право ЕС

Для цитирования: Зуев В.Н., Попова И.М. Европейский подход к управлению в сфере спорта: ценности, нормы и интересы // Вестник международных организаций. 2018. Т. 13. № 1. С. 51-65. DOI: 10.17323/19967845-2018-01-03

${ }^{1}$ Статья поступила в редакцию в сентябре 2017 г.

2 Участие В.Н. Зуева в данной работе было поддержано грантом факультета мировой экономики и мировой политики НИУ ВШЭ в 2018 г. 


\section{Источники}

Зуев В.Н. (2016) Глобальные институты регулирования: учебник. М.: Магистр; Инфра-М.

Andreff W. (2011) Some Comparative Economics of the Organization of Sports: Competition and Regulation in North American vs. European Professional Team Sports Leagues // The European Journal of Comparative Economics. Vol. 8. No. 1. P. 3-27.

Crolley L., Levermore R., Pearson G. (2002) For Business or Pleasure? A Discussion of the Impact of European Union Law on the Economic and Socio-Cultural Aspects of Football // European Sport Management Quarterly. Vol. 2. No. 4. P. 276-295.

European Commission (2007) European Model of Sport, Discussion Paper for the Working Group. Режим доступа: http://ec.europa.eu/sport/library/documents/b1/doc424_en.pdf (дата обращения: 19.01.2018).

Garcia B. (2007) UEFA and the European Union: From Confrontation to Co-Operation? // Journal of Contemporary European Research. Vol. 3. P. 202-223.

Hill J. (2009) The European Commission's White Paper on Sport: a Step Backwards for Specificity? // International Journal of Sport Policy. Vol. 1. No. 3. P. 253-266.

Holt M. (2006) UEFA, Governance and the Control of Club Competition in European Football. L.: Football Governance Research Centre, Birbeck University of London.

Inthorn S. (2010) Europe Divided, or Europe United? German and British Press Coverage of the 2008 European Championship // Soccer \& Society. Vol. 11. No. 6. P. 790-802.

Levermore R., Millward P. (2007) Official Policies and Informal Transversal Networks: Creating "PanEuropean Identifications” through Sport? // The Sociological Review. Vol. 55. No. 1. P. 144-164.

Martin P. (2005) The "Europeanization" of Elite Football // Scope, Meanings and Significance. European Societies. Vol. 7. No. 2. P. 349-368.

Parrish R. (2003) The Politics of Sports Regulation in the European Union // Journal of European Public Policy. Vol. 10. No. 2. P. 246-262.

Parrish R. (2003) The Birth of European Union Sports Law // Entertainment Law. Vol. 2. No. 2. P. 20-39. 